\title{
Managed Multi-strata Tree + Crop Systems: An Agroecological Marvel
}

\section{P. K. Ramachandran Nair* \\ School of Forest Resources and Conservation, University of Florida, Gainesville, FL, United States}

Today, when the emphasis on single-species production systems that is cardinal to agricultural and forestry programs the world over has resulted in serious ecosystem imbalances, the virtues of the time-tested practice of growing different species together as in managed Multi-strata Tree + Crop (MTC) systems deserve serious attention. The coconut-palm-based multispecies systems in tropical homegardens and shaded perennial systems are just two such systems. A fundamental ecological principle of these systems is niche complementarity, which implies that systems that are structurally and functionally more complex than crop- or tree monocultures result in greater efficiency of resource (nutrients, light, and water) capture and utilization. Others include spatial and temporal heterogeneity, perennialism, and structural and functional diversity. Unexplored or under-exploited areas of benefits of MTC systems include their ecosystem services such as carbon storage, climate regulation, and biodiversity conservation. These multispecies integrated systems indeed represent an agroecological marvel, the principles of which could be utilized in the design of sustainable as well as productive agroecosystems. Environmental and ecological specificity of MTC systems, however, is a unique feature that restricts their comparison with other land-use systems and extrapolation of the management features used in one location to another.

Keywords: agroforestry, biodiversity conservation, carbon sequestration, specialty crops, tropical homegardens, shaded perennial systems

\section{INTRODUCTION}

Some agricultural historians trace back the technological innovations in agriculture to Jethro Tull's invention of the seed drill in 1701. Others consider the scientific investigations on the use of fertilizers that began at the Rothamsted Experimental Station in England in 1843 as the true beginning of technological agriculture. Nevertheless, the dramatic increase in global agricultural production is a phenomenon of the second half the twentieth century. Out of the nearly $200 \%$ increase in grain production during that period, only about $30 \%$ was the result of increases in area under cultivation; the remaining was made possible by increases in yield per unit area through technology-based agricultural intensification, the so-called Green Revolution (Borlaug, 2007).

These accomplishments have indeed been remarkable. Agricultural intensification, however, is reported to have caused or exacerbated several environmental problems including accelerated soil erosion and degradation, water-quality decline and lowering of water tables, greenhouse-gas build-up and climate change, and biodiversity decline (Mueller et al., 2012). The society at large had to pay a huge overall "price" for reaping the benefits, and yet the benefits were beyond the reach of the vast majority of poor farmers. Moreover, it became infeasible to sustain these benefits in the long run (Pingali, 2012). Furthermore, disruption of intergenerational equity resulting from excessive use of finite resources beyond the regenerative capabilities of nature might deprive the future generations of their ability to 
access their rightful share of natural capital (Daily and Ehrlich, 1996; Costanza et al., 1997). Today, the importance of conserving the natural resource capital of soil, water, air, and biodiversity is also being recognized while maintaining the main focus on enhancing production of preferred commodities. All these activities are rooted in the notion that modern agricultural and forestry production systems have to be in single-species stands. They entail line planting of plants of uniform age, and if possible genetic make-up, at specified spacing between rows and plants within the rows and monotonously uniform fields. On the other hand, such artificially created landscapes are not found in nature. In the drive for maximizing yield and profit, the age-old farming systems involving plant associations of crops and trees of various forms have been ignored.

The ecosystem imbalance caused by the over-emphasis on single-species production systems is a very complex issue. We certainly need to increase land productivity to meet the growing demands of food and fiber, for which use of non-renewable inputs is considered essential. At the same time we also need to reduce the use of these inputs for the sake of environment and ecology. In the search for such land-use systems, the multi-species treebased farming systems, based on the age-old practice of growing different species together, deserve serious attention. Although they are not major food-producing systems, there are important lessons to be learned from these agroecosystems that maintain their ecological integrity in spite of being continuously impacted by human exploitation of the wide variety of products and services. This paper assesses the unique characteristics of such managed Multi-strata Tree + Crop (MTC) systems, explores the ecological foundations upon which they are grounded, and argues for finding ways to extrapolate those principles to other land-use systems.

\section{MANAGED MULTI-STRATA TREE + CROP SYSTEMS}

Integrated MTC systems are found all over the world. Indeed, wherever land is not deliberately brought under single species systems of crops and trees as in agricultural/grazing, horticultural, and forestry operations, the vegetation will consist of multi-species stands. But, managed MTC systems are a predominant land-use feature of warmer parts of the world, and are an important category of agroforestry systems (AFS).Two groups of such systems with unique characteristics that have received some scientific attention are considered here along with their ecosystem characteristics and resource-utilization features.

\section{Coconut-Palm-Based Multispecies Systems and Homegardens}

Palms, belonging to the distinctive botanical family Palmae or Arecaceae, are among the most common perennial plants (trees) and are distributed in the tropical and subtropical regions (Johnson, 2011; Smith, 2014). The most widely cultivated among them is the coconut palm (Cocos nucifera), one of the earliest domesticated plants; its uses are legion (Purseglove, 1972). Unlike other cultivated palms that are grown mostly in sole stands, the coconut is usually grown in intimate association with other species, making it perhaps the most widely intercropped tree. The palm has been and still is an inseparable part of the sociocultural heritage and economic wellbeing of the inhabitants of its major growing regions. Because of the high population density and small landholding sizes in such regions, coconuts are grown mostly in smallholder farms of less than 2 ha. Being a singlestemmed perennial with no cambium, the main stem (trunk) of the palm does not increase in girth with age, and its apical crown at the growing tip of the trunk contains 30-40 long leaves at any time and a fairly constant-sized crown with a diameter of about $7 \mathrm{~m}$ throughout its adult life from about 10 to 70 years. In a planted stand of palms of same age, this characteristic growth habit allows considerable light penetration to the plantation floor as the palm grows taller with age, allowing growth of other species under or between them. Thus, smallholder farms of coconut consist mostly of palms in association with a variety of other specialty species of all types: herbs, shrubs, vines, and trees (Figure 1), all managed as family-farm enterprises.

Numerous reports are available on the extent of intercropping and the types of crops grown in different countries and regions. The species so intercropped consist of food crops including roots and tubers, fruit trees and MPT, medicinal plants, and others that provide multiple products such as food, fuel, fodder, timber, medicine, and such other basic necessities, and help meet the cash requirements of the growers (Kumar, 2011). These integrated farming systems generally outperform the normal or commercial farming systems in all four dimensions of a multifunctional agriculture: food security, environmental functions, economic functions, and social functions (Tipraqsa et al., 2007).

Homegardens, especially in the tropics, present the most intense assemblage species in a managed community of plants. Coconut palms and several other fruit- and nut-producing species and crops are dominant components of such systems in homesteads in different parts of the world, most notably in the highly populated regions of South and Southeast Asia (Kumar and Nair, 2006). Concerns have been raised about the likelihood of labor-intensive homegardens being replaced by commercial

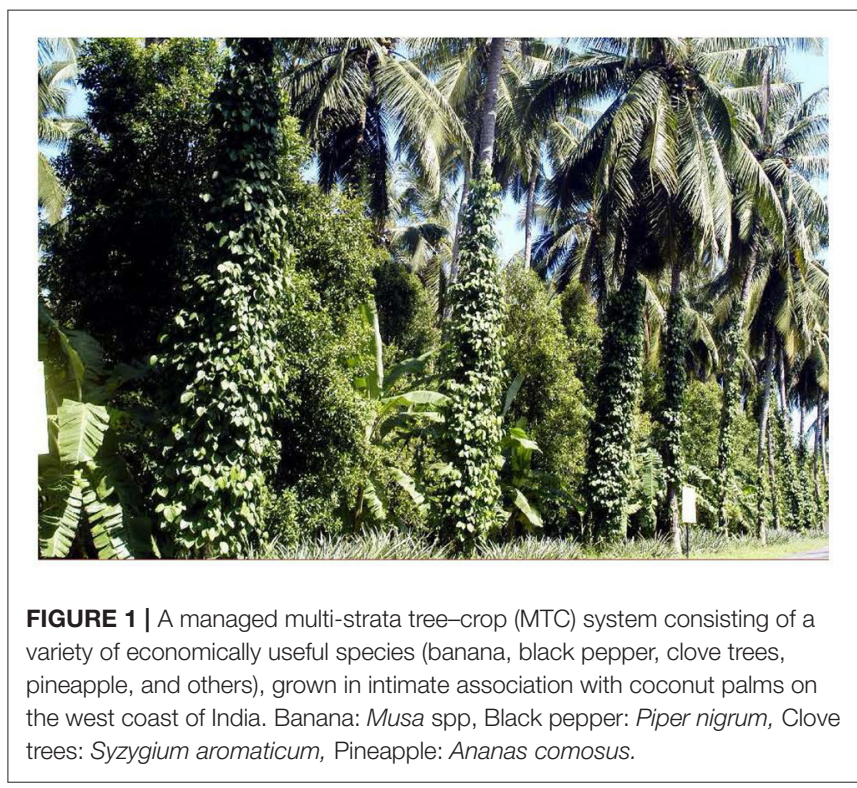


farming in the wake of socioeconomic and technological changes. Recent studies in Kerala, India, a well-known hotspot of tropical homegardens, however, have found little evidence for such apprehensions (Fox et al., 2017).

The ecological, managerial, and socio-cultural attributes of tropical homegardens can also be found in similar approaches to multispecies system management such as permaculture (Permanent Agriculture: Mollison, 1994), and Forest Farming (Hart, 1993) that is now gaining popularity in the UK (Pilgrim, 2014). Numerous other such integrated systems are practiced around the world; but several of them are seldom known outside their places of existence. Nair et al. (2016) described them as Cinderella AFS that hold enormous promise for the future if they are brought under the realm of modern research. While tracing the history of development of agroforestry, several authors have described how many of the AFS of today have evolved from such indigenous systems around the world (Herzog, 1998; Kumar and Nair, 2006, 2011; Miller and Nair, 2006; Papanastasis et al., 2009).

\section{Shaded Perennial Systems}

"Shaded perennial system" is a term that is used in agroforestry literature for managed, vertically stratified plant associations involving shade-tolerant and/or shade-adapted crops under tallgrowing trees. The overstory species of these combinations include those that are either deliberately planted as shade trees as in plantations of cacao (Theobroma cacao), coffee (Coffea spp.), and tea (Camellia sinensis). A large number of economic tree/shrub/vine species are grown under such partial-shade conditions in a variety of situations. Excellent examples of such traditional specialty crop associations from the Pacific Islands are described by Elevitch $(2006,2011)$. Non-traditional species that are getting popularized lately in such systems include a variety of perennial species such as moringa (Moringa oleifera) and highvalue specialty species such as sandalwood (Santalum spp.) (S. Viswanath, personal communication, 2017).

Information on the extent of area under shaded perennial systems is not readily available. Cacao, a native of the Amazon region, is an understory species in its native habitat, and is cultivated almost exclusively under the shade of a variety of trees and banana. As for coffee, the shade vs. sun coffee discussion is as old as the history of coffee cultivation itself. While coffee grown under shade ("shade coffee") is unquestionably superior to "sun coffee" in terms of aroma and taste and fetches much higher price, the area under shade coffee has gradually been declining because of economic reasons: sun-grown coffee cultivated with rather heavy input of chemicals to keep insects, diseases, and weeds under check far out-yield shade coffee. According to the Millennium Ecosystem Assessment (MEA, 2005), shaded perennial AFS render ecosystem services with high value for supporting human livelihoods include carbon storage, regulation of climate, biodiversity conservation, provision of clean water, and maintenance of soil fertility.

Although the two types of systems mentioned above share the multi-strata canopy configuration that is characteristic of all MTCs, structurally and functionally these systems are different. The shaded perennial systems usually contain only two major, usually woody, species whereas the homegardens consist of higher number of plant species of different forms (trees, shrubs, herbs, vines). Another difference is the extent of socio-cultural interplay in the management of these systems. Homegardens are in smallholder family farms of less than a hectare area, managed mostly by family labor with minimal to no use of chemicals and machinery, whereas shaded perennial systems are commercial operations involving hired labor and machinery.

\section{ECOLOGICAL FOUNDATIONS OF MULTI-SPECIES SYSTEMS \\ Niche Complementarity}

One of the ecological foundations of the MTC systems is the Niche Complementarity Hypothesis (Harper, 1977), which states that "a larger array of species in a system leads to a broader spectrum of resource utilization making the system more productive, and leads to better and more efficient use and sharing of resources." This implies that land-use systems that are structurally and functionally more complex than either crop- or tree monocultures result in greater efficiency of resource (nutrients, light, and water) capture and utilization, and greater structural diversity that entails tighter nutrient cycles. As Tilman and Snell-Rood (2014) have stated, "niche differences among species help to explain why large numbers of competing species coexist, and why greater plant diversity leads to greater ecosystem productivity." While the above- and below-ground diversity provides more system stability and resilience at the site-level, the systems provide connectivity with forests and other landscape features at the landscape and watershed levels.

\section{Systems Perspective}

A common thread found in the many definitions and descriptions of AFS/MTCs is their multi-faceted nature. Spatial and temporal heterogeneity, perennialism, and the structural and functional diversity are the ecological properties that are fundamental to such systems (Nair et al., 2008). Comparisons are usually made with natural forested or agroecosystems in terms of the extent to which these properties are maintained in AFS. For example, compared with the net primary productivity of $2-$ $6 \mathrm{Mg}$ dry matter (biomass) ha ${ }^{-1}$ year $^{-1}$ (depending on species) for temperate coniferous forest plantations, the multi-strata homegardens and shaded perennial systems of the tropics can have in excess of $15 \mathrm{Mg} \mathrm{ha}^{-1}$ year $^{-1}$. The ecological indices for species similarity, diversity, and richness (Sorenson's, ShannonWiener, and Margalef, respectively) of multispecies homegardens are similar to those of nearby primary forests (Kumar, 2011). These similarities with natural ecosystems are strong indicators of ecological sustainability.

\section{Ecosystem Services}

A major area of relatively unexplored potential of the MTC systems is their ecosystem services. Among the several such services that are mentioned as potential benefits (Minang and Sassen, 2015), carbon sequestration and biodiversity are two that have received some research attention lately. In these systems, a significant part of the nearly $25 \%$ of total biomass production that goes into roots will remain in the soil for periods longer than 
in annual cropping systems. Scientific data accumulated over the past 20 years of our work show increase in soil carbon (C) stock under agroforestry system under different ecological conditions, and a higher percentage of that $\mathrm{C}$ in AFS (compared to treeless systems) is in smaller (silt-and-clay) fractions of soil, indicating recalcitrant nature and long-term storage of $\mathrm{C}$. Increase in soil organic carbon stock, which is important from the soil-fertilityimprovement as well as environmental-amelioration (carbon sequestration) points of view.

Biodiversity is proving to be one of humanity's best defenses against extreme weather and rising temperatures; protecting it is important for keeping the ecosystems working for us, providing food, absorbing waste, and protecting shorelines (Duffy et al., 2017). The inherently high level of biodiversity of multispecies systems offers several possibilities for arrangement of various tree/shrub/and grass components according to the needs and preferences of farmers. For example, Webb and Kabir (2009) reported, based on an extensive study in Bangladesh, that the ubiquitous homegardens covered more than $12 \%$ of the land area and provided the majority of tree-dominated habitats across the country. The authors articulated that homegardens represented the only real opportunity to conserve plant and wildlife populations outside of the beleaguered protected-area system. It remains unclear, however, whether few or many of the species in an ecosystem are needed to sustain the provisioning of ecosystem services. Isbell et al. (2011) showed, based on a study of 17 biodiversity experiments, that although species diversity may appear functionally redundant for one set of environmental conditions, many species are needed to maintain multiple functions at multiple times and places in a changing world.

\section{FUTURE SCENARIOS AND DIRECTIONS}

Environmental and ecological specificity of MTC systems is a unique feature that restricts the comparison of systems at different locations and extrapolation from one location to another. This issue needs to be analyzed in the context of current research advances in the broad arena of land-use systems. Admittedly, the Green Revolution is perceived as the most impactful advance in this area during post-World War II era, and has become a standard against which other advances are compared. Although substantial advances have been made on several fronts such as climate-change mitigation and adaptation, and the use of computer modeling and GMOs (genetically modified organisms) to name a few, they pale when compared to the above-referenced "standard."

A case in point is computer modeling. From the perspective of MTC systems, the scenario is rather hazy. Most of the seemingly reliable crop models are limited to single-species systems where the interaction between plants are restricted to resource utilization among same species (Steduto et al., 2009). This is not to ignore or belittle the modeling work on intercropping systems, and on tree-crop interactions including WaNuLCAS (VanNoordwijk and Lusiana, 1998) and the SAFE family of models (Vander Werf et al., 2007; Graves et al., 2011). As Luedeling et al. (2014) and Bayala et al. (2015) have pointed out, the complex nature of arrangement of species within agroforestry systems hinders the progress in their modeling. Research-based knowledge on the specific management for each component while grown in combination with other species, and the scope for development of varieties are two important management-related research priorities. These are equally challenging to both modelers and field-oriented researchers.

The increasing importance being given to largescale computer models and predictions also is noteworthy in this context. Numerous estimates are available on the potential and magnitude of various ecosystem services; for example, global estimations and predictions on $\mathrm{C}$ sequestration (Paustian et al., 2016), and global economic valuations of ecosystem services (Kubiszewski et al., 2017). Costanza et al. (2014) estimated that between 1997 and 2011 the global value of these services decreased by an estimated USD 20 trillion/year due to land-use change. Kubiszewski et al. (2017) predicted that under different scenarios, the global value of ecosystem services could decline by $\$ 51$ trillion/year or increase by USD $\$ 30$ trillion/year. To what extent such valuations are meaningful, and whether the site-specificity of agroecosystems is factored into such global estimations are unknown. Given the extremely site-specific nature of the MTC systems, studies at the field level should be the starting points for valuing the benefits of their ecosystem services. Furthermore, often they are expressions of interactions involving not only easily measurable biophysical factors but also difficultto-quantify sociocultural factors. This is particularly true in lowresource farming situations in the tropics where such practices are common.

The accumulated weight of evidence emerging from various activities of similar nature including the consistency of experience across geographical regions supports the conclusion that these integrated MTCs represent an agroecological marvel. Unfortunately such systems have not received deserving research and policy attention. This is primarily because they do not fit into the single-species model of agricultural development paradigms. Serious efforts are needed to learn the principles based upon which these systems have stood the test of time. When properly understood, those principles could be applied for improvement of extensive food-production systems such as intercropping of annual crops (e.g., maize and beans in Africa and Latin America), and the extensive parkland systems of Africa.

\section{AUTHOR CONTRIBUTIONS}

The author confirms being the sole contributor of this work and approved it for publication.

\section{ACKNOWLEDGMENTS}

Nilovna Chatterjee helped with literature collection especially related to application of modeling in agricultural systems, and Vimala Nair read through the manuscript.

This work was supported by USDA/NIFA/Mcintire-Stennis Project FLA-FOR-005249, Accession Number 233673; the views expressed are the author's and not of USDA/NIFA. 


\section{REFERENCES}

Bayala, J., Sanou, J., Teklehaimanot, Z., and Sinclair, F. (2015). "Adaptation of crops to partial shade in mixed cropping systems," in Tree-Crop Interactions: Agroforestry in a Changing Climate, eds C. Black, J. Wilson and C. K. Ong (Wallingford: CABI), 309-325.

Borlaug, N. E. (2007). Sixty-two years of fighting hunger: personal recollections. Euphytica 157, 287-297. Available online at: http://repository.cimmyt.org/ xmlui/handle/10883/1926? show=full

Costanza, R., de Groot, R., Sutton, P. C., van der Ploeg, S., Anderson, S., Kubiszewski, I., et al. (2014). Changes in the global value of ecosystem services.Glob. Environ. Change 26, 152-158. doi: 10.1016/j.gloenvcha.2014.04.002

Costanza, R., d'Arge, R., de Groot, R., Farber, S., Grasso, M., Hannon, B., et al. (1997). The value of the world's ecosystem services and natural capital. Nature $387,253-260$.

Daily, G. C., and Ehrlich, P. R. (1996). Socioeconomic equity, sustainability, and Earth's carrying capacity. Ecol. Appl. 6, 991-1001.

Duffy, J. E., Godwin, C. M., and Cardinale, B. J. (2017). Biodiversity effects in the wild are common and as strong as key drivers of productivity. Nature 549, 261-264. doi: 10.1038/nature23886

Elevitch, C. R. (ed.). (2006). Traditional Trees of Pacific Islands. Holualoa, HI: Permanent Agriculture Resources.

Elevitch, C. R. (ed.). (2011). Specialty Crops for Pacific Islands. Holualoa, HI: Permanent Agriculture Resources.

Fox, T. A., Rhemtulla, J. M., Ramankutty, N., Lesk, C., Coyle, T., and Kunhamu, T. K. (2017). Agricultural land-use changes in Kerala, India: perspectives from above and below the canopy. Agric. Ecosyst. Environ. 245, 1-10. doi: 10.1016/j.agee.2017.05.002

Graves, A. R., Burgess, P. J., Liagre, F., Terreaux, J.-P., Borrel, T., Dupraz, C., et al. (2011). Farm-SAFE: the process of developing a plot- and farm-scale model of arable, forestry, and silvoarable economics. Agroforestry Syst. 81, 93-108. doi: 10.1007/s10457-010-9363-2

Harper, J. L. (1977). Population Biology of Plants. New York, NY: Academic Press.

Hart, R. (1993). The Forest Garden. London: The Institute of Social Innovations.

Herzog, F. (1998). Streuobst: a traditional agroforestry system as a model for agroforestry development in temperate Europe. Agroforestry Syst. 42, 61-80.

Isbell, F., Calcagno, V., Hector, A., Connolly, J., Harpole, W. S., Reich, P. B., et al. (2011). High plant diversity is needed to maintain ecosystem services. Nature 477, 199-202. doi: 10.1038/nature10282

Johnson, D. V. (2011). Tropical Palms. 2010 Revision. Non-Wood Forest Products 10/Rev. 1. FAO, Rome.

Kubiszewski, I., Costanza, R., Anderson, S., and Sutton, P. (2017). The future value of ecosystem services: global scenarios and national implications. Ecosyst. Serv. 26, 289-301. doi: 10.1016/j.ecoser.2017.05.004

Kumar, B. M. (2011). Species richness and aboveground carbon stocks in the homegardens of central Kerala, India. Agric. Ecosyst. Environ. 140, 430-440. doi: 10.1016/j.agee.2011.01.006

Kumar, B. M., and Nair, P. K. R. (eds). (2006). Tropical Homegardens: A TimeTested Example of Sustainable Agroforestry. Advances in Agroforestry, Vol. 3. Dordrecht: Springer Science, 390.

Kumar, B. M., and Nair, P. K. R. (eds). (2011). Carbon Sequestration in Agroforestry Systems: Opportunities and Challenges. Advances in Agroforestry, Vol. 8. Dordrecht: Springer Science, 307.

Luedeling, E., Huth, N. I., Kindt, R., and König, K. (2014). Agroforestry systems in a changing climate - challenges in projecting future performance. Curr. Opin. Environ. Sustain. 6, 1-7. doi: 10.1016/j.cosust.2013. 07.013
MEA (2005). Millennium Ecosystem Assessment: Ecosystems and Human WellBeing: Synthesis. Washington, DC: Island Press

Miller, R. P., and Nair, P. K. R. (2006). Indigenous agroforestry systems in Amazonia: from prehistory to today. Agroforestry Syst. 66, 151-164. doi: 10.1007/s10457-005-6074-1

Minang, P. A., and Sassen, M. (2015). An Ecosystem Services Based Analysis of Agroforestry Systems. Nairobi: ICRAF/UNEP

Mollison, B. (1994). Introduction to Permaculture. Tyalgum, NSW: Tagari Publications

Mueller, N., Gerber, J., Johnston, M., Ray, D., Ramankutty, N., and Foley, J. (2012). Closing yield gaps through nutrient and water management. Nature 490, 254-257. doi: 10.1038/nature 11420

Nair, P. K. R., Gordon, A. M., and Mosquera-Losada, M.-R. (2008). “Agroforestry,” in Ecological Engineering, Vol [1] of Encyclopedia of Ecology, 5 Vols, eds S. E. Jorgensen and B. D. Fath (Oxford: Elsevier), 101-110.

Nair, P. K. R., Viswanath, S., and Lubina, P. A. (2016). Cinderella agroforestry systems. Agroforestry Syst. 91, 901-917. doi: 10.1007/s10457-016-9966-3

Papanastasis, V. P., Mantzanas, K., Dini-Papanastasi, O., and Ispikoudis, I. (2009). "Traditional agroforestry systems and their evolution in Greece," in Agroforestry in Europe, eds A. Rigueiro-Rodríguez, J. McAdam, and M. R. Mosquera-Losada (Dordrecht: Springer), 89-110.

Paustian, K., Lehmann, J., Ogle, S., Reay, D., Robertson, G. P., and Smith, P. (2016). Climate-smart soils. Nature 532, 49-57. doi: 10.1038/nature17174

Pilgrim, E. S. (2014). Dining on Forest Food: Lesson from the Tropics. London: British Ecological Society.

Pingali, P. L. (2012). Green revolution: impacts, limits, and the path ahead. Proc. Natl. Acad. Sci. U.S.A. 109, 12302-12308. doi: 10.1073/pnas.0912953109

Purseglove, J. (1972). Tropical Crops: Monocotyledons. London: Longman.

Smith, N. J. H. (2014). Palms and People in the Amazon. Dordrecht: Springer, 500.

Steduto, P., Hsiao, T. C., Raes, D., and Fereres, E. (2009). Aquacrop-the FAO crop model to simulate yield response to water: I. concepts and underlying principles. Agron. J. 101, 426-437. doi: 10.2134/agronj2008.0139s

Tilman, D., and Snell-Rood, E. (2014). Diversity breeds complementarity. Nature 515, 44-45. doi: 10.1038/nature13929

Tipraqsa, P., Craswell, E. T., Noble, A. D., and Schmidt-Vogt, D. (2007). Resource integration for multiple benefits: Multifunctionality of integrated farming systems in Northeast Thailand. Agric. Syst. 94, 694-703. doi: 10.1016/j.agsy.2007.02.009

Webb, E. L., and Kabir, M. E. (2009). Homegardening for tropical biodiversity conservation. Conserv. Biol. 23, 1641-1644. doi: 10.1111/j.1523-1739.2009.01267.x

VanNoordwijk, M., and Lusiana, B. (1998). WaNulCAS, a model ofwater, nutrient and light cap- ture in agroforestry systems. Agroforestry Syst. 43, 217-242.

Vander Werf, W., Keesman, K., Burgess, P., Graves, A., Pilbeam, D., Incoll, L. D., et al. (2007). Yield-SAFE: a parameter-sparse, process-based dynamic model for predicting resource capture, growth, and production in agroforestry systems. Ecol. Eng. 29, 419-433. doi: 10.1016/j.ecoleng.2006.09.017

Conflict of Interest Statement: The author declares that the research was conducted in the absence of any commercial or financial relationships that could be construed as a potential conflict of interest.

Copyright (c) 2017 Nair. This is an open-access article distributed under the term of the Creative Commons Attribution License (CC BY). The use, distribution or reproduction in other forums is permitted, provided the original author(s) or licensor are credited and that the original publication in this journal is cited, in accordance with accepted academic practice. No use, distribution or reproduction is permitted which does not comply with these terms. 